\title{
Will reconnecting ecosystems allow long-distance mammal migrations to resume? A case study of a zebra Equus burchelli migration in Botswana
}

\author{
H.L.A. B A R T LA M-BRoOKS, M. C. BONYONGO and S TEPHEN HARR IS
}

\begin{abstract}
Terrestrial wildlife migrations, once common, are now rare because of ecosystem fragmentation and uncontrolled hunting. Botswana historically contained migratory populations of many species but habitat fragmentation, especially by fences, has decreased the number and size of many of these populations. During a study investigating herbivore movement patterns in north-west Botswana we recorded a long-distance zebra Equus burchelli antiquorum migration between the Okavango Delta and Makgadikgadi grasslands, a round-trip distance of $588 \mathrm{~km}$; $55 \%$ of 11 animals collared in the south-eastern peripheral delta made this journey. This was unexpected as, between 1968 and 2004, the migration could not have followed its present course because of the bisection of the route by a veterinary cordon fence. As little evidence exists to suggest that largescale movements by medium-sized herbivores can be restored, it is of significant interest that this migration was established to the present highly directed route within 4 years of the fence being removed. The success of wildlife corridors, currently being advocated as the best way to reestablish ecosystem connectivity, relies on animals utilizing novel areas by moving between the connected areas. Our findings suggest that medium-sized herbivores may be able to re-establish migrations relatively quickly once physical barriers have been removed and that the success of future system linkages could be increased by utilizing past migratory routes.
\end{abstract}

Keywords Botswana, Equus burchelli antiquorum, fencing, GPS, migration, ungulate, wildlife corridor

\section{Introduction}

Tistorically, migrations or long-distance seasonal 1 movements were common in a wide range of marine, freshwater and terrestrial taxa (Berger, 2004). Terrestrial mammal migrations, defined by Berger (2004) as 'seasonal movements between discrete areas that are not used at other times of the year', used to occur in most grassland

H.L.A. Bartlam-Brooks (Corresponding author) and Stephen Harris School of Biological Sciences, University of Bristol, Woodland Road, Bristol, BS8 1UG, UK. E-mail hattie.bartlam@bristol.ac.uk

M.C. Bonyongo Harry Oppenheimer Okavango Research Institute, University of Botswana, Maun, Botswana

Received 18 January 2010. Revision requested 10 March 2010.

Accepted 7 April 2010. and boreal forest ecosystems in Africa, Asia, Europe and North America (Fryxell et al., 1988; Dingle, 1996). These may have evolved to enhance access to high-quality food or to reduce predation risk (Fryxell \& Sinclair, 1988). Because ungulate survival has been linked to the quality rather than absolute abundance of available resources (Fryxell, 1987), any strategy that allows ungulates to select higher quality resources may improve survival chances. Thus in the Serengeti-Mara ecosystem, wildebeest Connochaetes taurinus, zebra Equus burchelli and Thompson's gazelle Eudorcas thomsonii move in response to seasonal variations in mineral and protein content of preferred forage rather than to variations in forage abundance (Sinclair \& Arcese, 1995), although overall survival is regulated by the abundance of dry season forage (Mduma et al., 1999).

In Africa migrations numbering millions of animals were common until the 19th century (Roche, 2008). However, these have declined dramatically in both number and size over the last century and many of those that still occur are believed to be under threat (Berger, 2004), primarily from uncontrolled hunting and habitat fragmentation because of human encroachment from arable farming, pastoralism and urbanization (Harris et al., 2009). The large ranges required by migratory populations are particularly affected by habitat fragmentation because few migration routes are completely within protected areas. Because migratory populations are only maintained by their ability to undertake seasonal movements to areas of higher resource quality/lower predation risk, they rapidly decline once migration routes are blocked and seasonal ranges are no longer accessible (Williamson et al., 1988; Perkins, 1996; Bolger et al., 2008).

Historically many ungulate migrations occurred in Botswana. The largest existed around the Kalahari Desert, with animals spending the dry season either without access to water or around permanent water before moving to seasonal desert grasslands once rain had filled temporary waterholes and initiated the growth of annual grasses (Williamson et al., 1988). Millions of wildebeest, hartebeest Alcelaphus buselaphus and springbok Antidorcas marsupialis moved from the central Kalahari Desert to the schwelle grassland in south-west Botswana (Williamson et al., 1988) and hundreds of thousands of wildebeest and zebra moved from the Boteti River to the Kalahari and Makgadikgadi grasslands (Kgathi \& Kalikawe, 1993). Further north, buffalo Syncerus caffer, elephant Loxodonta africana, wildebeest 
and zebra moved from the permanent waters of the Okavango and Linyanti river systems to the seasonal grasslands of the Savuti Marsh (Vandewalle, 2000).

Between the 1950s and 1980s, Botswana erected veterinary cordon fences across much of the country to prevent disease transmission between wildlife and cattle, especially those destined for European export (Keene-Young, 1999). These $1.3 \mathrm{~m}$ high cable fences were put up rapidly with little information on potential impacts on wildlife movements or ranges (Perkins, 1996). Although the deployment of fences gave increased protection for wildlife in specified areas, many migratory movements were disrupted. Reversing such ecosystem fragmentation is increasingly being seen as an important strategy to ensure long-term species survival (Diamond, 1975). However, so far there is little evidence to suggest that traditional large-scale movements by medium-sized herbivores can be restored.

The original aim of our study was to investigate regional distribution and movement patterns of medium-sized herbivores in north-west Botswana. Because the traditional migratory routes out of the Okavango Delta towards the Kalahari grasslands had been severed by the veterinary cordon fences, no long-distance movements were predicted. Here, we report on a long-distance zebra E. burchelli antiquorum migration established shortly after decommissioning of a long-standing fence.

\section{Study area}

The study was conducted from July 2007 to November 2009 in the Moremi Game Reserve in the Okavango Delta and Makgadikgadi and Nxai Pan National Parks in the northern Kalahari, Botswana (Fig. 1) and surrounding wildlife management areas. The region has two distinct seasons, with rain primarily occurring during NovemberApril. Normal rain patterns occurred in 2007-2008, whereas in 2008-2009 unseasonal heavy rain fell in May and June (Fig. 2). The Okavango Delta also floods annually, with flood water arriving in March and reaching the distal delta by July (Andersson et al., 2003). The duration of inundation of seasonal flood plains varies with local topography, cyclic variation of flood water and progression of the water flow through the delta, which occurs in a south-easterly direction (Andersson et al., 2003). For this study areas that flooded for $>3$ months per year were designated as central delta and those that flooded for $<3$ months per year as peripheral delta.

\section{Methods}

Between July and October 2007 we fitted global positioning system (GPS) collars (Vectronic GPS-Plus 4D; Vectronic Aerospace $\mathrm{GmbH}$, Berlin, Germany), to 21 randomly selected adult zebra mares from different harems: seven in the central delta and 14 in the peripheral delta. To collect further data on long-distance movements in August 2008 we fitted a further five GPS collars (Vectronic GPS-Plus IRIDIUM 4D; Vectronic Aerospace GmbH, Berlin, Germany) to adult zebra mares in harems in the vicinity of collared zebra that had migrated in 2007. All collars also had a VHF tracking unit. Stallions were not collared to reduce the risk of collar damage from intrasexual fighting. Because zebra live in harems that include different age and sex cohorts, collaring only mares does not introduce biases because of sex- and age-specific movement patterns and/or spatial preferences (Klingel, 1969). The collars weighed $0.95 \mathrm{~kg}$; i.e. less than $0.3 \%$ of the total body weight of a Southern African zebra mare (mean weight $320 \mathrm{~kg}$; Skinner \& Smithers, 1990).

Zebra were darted from a stationary vehicle by an experienced wildlife veterinarian and sedated with etorphine hydrochloride (M99; Logos Agvet, Johannesburg, South Africa; Ebedes, 1971); mean time from darting to immobilization was $8.32 \pm$ SD 4.32 minutes in 2007-2008 $(\mathrm{n}=40)$ and $7.44 \pm$ SD 3.35 minutes in 2008-2009 $(n=8)$. Collars were fitted securely at the top of the zebra's neck. Immobilization was then reversed with diprenorphine hydrochloride (M50-M50; Logos Agvet, Johannesburg, South Africa); mean time \pm SD immobilized was $13.52 \pm$ SD 6.43 minutes in 20072008 and $9.49 \pm$ SD 1.29 minutes in 2008-2009. All zebra recovered successfully; none showed any lasting effects and all were observed rejoining their harems. All 2007-2008 collars were removed after a mean of $216 \pm$ SD 88 days, using the same protocol except for one zebra, which was killed by predators before collar removal. Three of the five 2008-2009 collars were removed after a mean of $384 \pm$ SD 43 days; one zebra was killed by predators before collar removal and the remaining collar has yet to be recovered.

The collars were programmed to take hourly fixes except for the first 7 days of the month, when they took one fix every 15 minutes. Only $3 \mathrm{D}$ fixes with a dilution of precision (DOP) of $<3.5$ were used for analysis; these constituted $99.3 \%$ of fixes. The VHF component of all collars worked 24 hours per day. All zebra were tracked using radiotelemetry monthly by air or from a vehicle to determine or confirm their location.

\section{Results}

Eighteen of the 21 zebra collared in 2007 were included in the analysis: seven in the central delta and 11 in the peripheral delta; three in the peripheral delta were excluded as the collars failed before the dry-to-wet season transition. All seven zebra collared in the central delta remained in the Okavango Delta for the entire study period. Of the 11 zebra collared in the peripheral delta, six (55\%) left the delta in November 2007 and undertook long-distance movements in a south-easterly direction towards the Makgadikgadi grasslands. Of these, five returned to the Okavango Delta in 


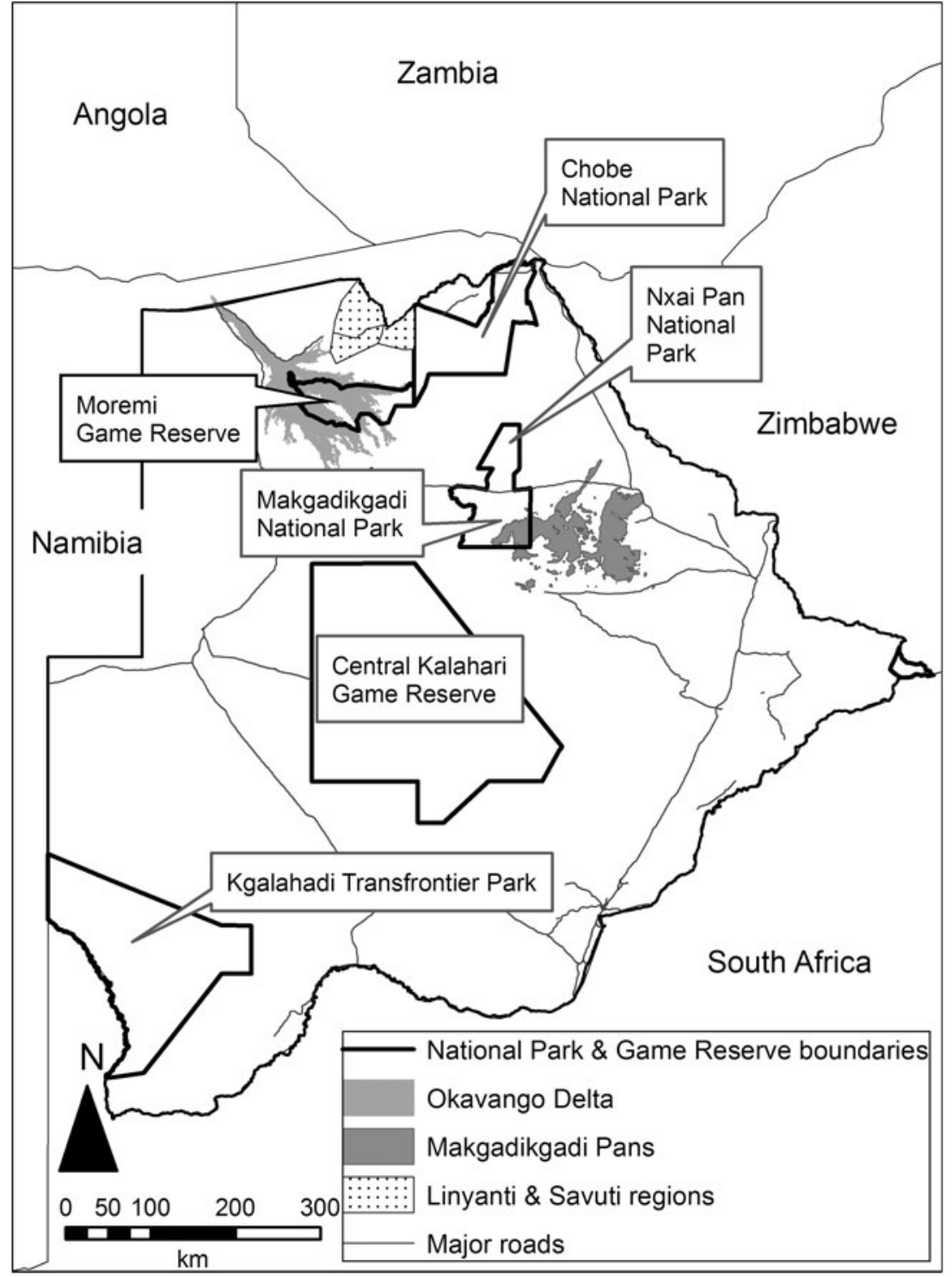

FIG. 1 Location of the main sites in Botswana referred to in the text.
May 2008 once the ephemeral waterholes in the Makgadikgadi grasslands had dried up. Because of failure of the GPS component on some collars, hourly GPS fixes detailing the migratory movements were only recorded for four zebra on the outward journey and two on the return journey; their movement data are summarized in Table 1. VHF tracking locations were used to confirm that the remaining zebra also migrated. The sixth zebra that moved to the Makgadikgadi grasslands did not return to the Okavango Delta the following dry season but remained on the Boteti River, on the western edge of the Makgadikgadi National Park (Fig. 1), before returning to the Makgadikgadi grasslands the following wet season.

In 2008 all five collared zebra left the peripheral delta in November 2008, returning in April 2009 (see Table 1 for movement statistics). However, the zebra returned to the Makgadikgadi after the unseasonal heavy rains in May
2009, remaining there until September 2009, when they returned to the peripheral delta, returning once more to the Makgadikgadi in October 2009 with the onset of the wet season (Fig. 2). The details of the movements from May 2009 onward were only recorded by one GPS collar because of collar failures. The heavy unseasonal rains in May and June 2009 may have contributed to the zebra making four distinct movements either to or from the Makgadikgadi within a year; the zebra with the working GPS collar travelled $972 \mathrm{~km}$ in long-distance movements between November 2008 and October 2009.

The route travelled from the delta to the Makgadikgadi was similar for all the GPS-collared zebra (Fig. 3) and between years. Animals moved in a directed fashion towards the corner of the fenced cattle ranches. Some animals spent a number of days to the north of the fence before continuing towards the Makgadikgadi. From this 


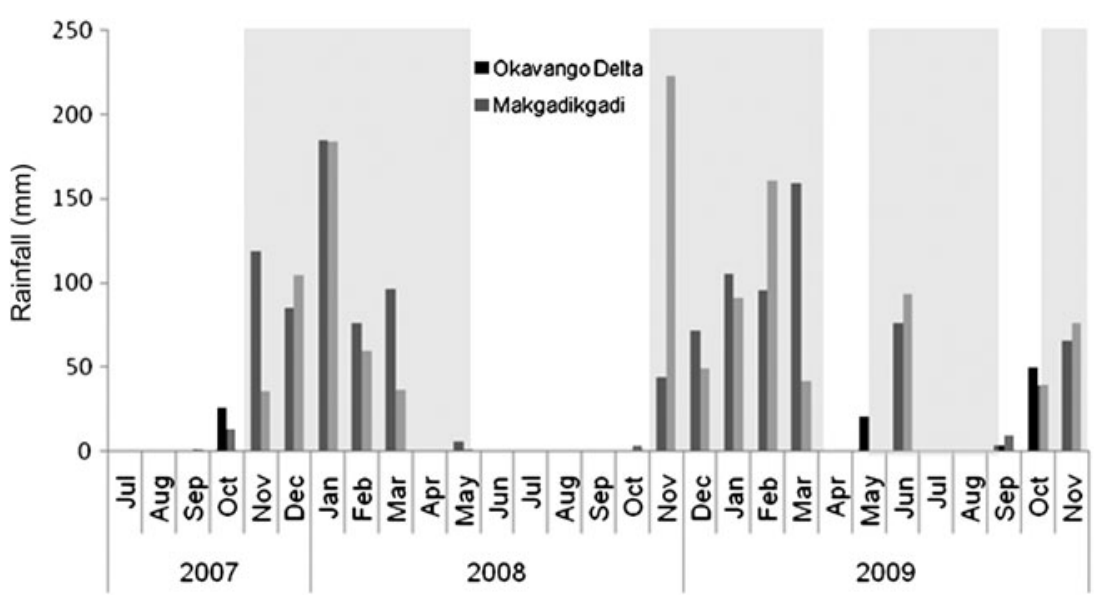

FIG. 2 Monthly rainfall in the Okavango Delta and Makgadikgadi Pans between July 2007 and November 2009. The rainfall data for the Okavango Delta are from Jacananet, recorded in Maun; the Makgadikgadi Pans data are from the Department of Wildlife and National Parks' site at Khumaga. The shaded areas indicate when the GPS-collared zebra were in the Makgadikgadi Pans, and the unshaded areas denote when they were in the Okavango Delta. point, zebra either took a more orientated route towards the Makgadikgadi or went via the Boteti River to the south.

\section{Discussion}

While it had been thought that migrations out of the Okavango Delta no longer occurred because of ecosystem fragmentation, we recorded a long-distance migration between the Okavango Delta and the Makgadikgadi grasslands to the south-east. In 2007-2008, the mean round trip was 588 $\mathrm{km}$, making it the longest zebra migration recorded in Botswana (Vandewalle, 2000; C.J. Brooks, pers. comm.). In Africa it is second only to the Serengeti-Mara migration, which covers $600-800 \mathrm{~km}$, although this distance is travelled over the course of a year (Sinclair \& Arcese, 1995). In contrast, the Okavango-Makgadikgadi zebra had two distinct relatively short phases of directed movement. In 2008-2009, perhaps in response to unseasonal rains, one zebra made the migratory journey four times within 12 months.

The zebras spent the dry season in the Okavango Delta, an intact and apparently productive wetland ecosystem in an otherwise arid area (McCarthy \& Ellery, 1998), moving to the Makgadikgadi grasslands for the rainy season. However, despite having an abundance of resources, grass quality in the delta is poor, with low concentrations of nitrogen and phosphorous associated with the nutrient-poor flood-water and the high proportion of Kalahari sands in the soil (Cronberg et al., 1996). In contrast, the Makgadikgadi grasslands lie on lacustrine soils that originated from a palaeolake (Baillieul, 1979) and seasonally support grasses of higher nutritional quality (Brooks, 2005). Thus, as in the Serengeti (Sinclair, 1979), the Botswana zebra appear to be moving to take advantage of higher quality resources rather than differences in the absolute abundance of grass. As has been found with other ungulate migrations (McNaughton, 1990), the movement trigger appeared to be the severe rainstorms that occur at the onset of the rainy season (H.L.A. Bartlam-Brooks, unpubl. data).

The migratory zebra from the Okavango Delta joined large numbers of zebra and wildebeest resident in the Makgadikgadi system, which were making long-distance movements from the Boteti River (Brooks \& Harris, 2008). The resulting large herds may also provide increased antipredator security for foals; initial observations suggest that peak in births in the migratory zebra coincides with their arrival in the Makgadikgadi grasslands (H.L.A. BartlamBrooks, unpubl. data), whereas peak in births of those that remain in the Delta coincides with the arrival of the floods in June. While further research is currently being undertaken into why the delta zebra did not stay with the resident herds in the Makgadikgadi year-round, previous investigations suggest that dry season resource quality is higher in the Okavango Delta (Bonyongo, 2004) than in the Boteti River region (Brooks, 2005).

The zebra followed a migratory route that was described anecdotally by explorers and hunters during the 20 th

TABle 1 Summary of the long-distance movement data of Equus burchelli antiquorum in Botswana (Figs 1 \& 3) recorded by GPS collars.

\begin{tabular}{|c|c|c|c|c|}
\hline Year & Movement & $\begin{array}{l}\text { Mean distance } \\
\pm \mathrm{SD}(\mathrm{km})\end{array}$ & $\begin{array}{l}\text { Mean duration } \\
\pm \text { SD (days) }\end{array}$ & $\begin{array}{l}\text { Travel speed } \\
\pm \mathrm{SD}(\mathrm{km} / \text { day })\end{array}$ \\
\hline \multirow[t]{2}{*}{$2007-2008$} & Delta-Makgadikgadi $(\mathrm{n}=4)$ & $286 \pm 33$ & $20.3 \pm 7.1$ & $15.2 \pm 4.7$ \\
\hline & Makgadikgadi-Delta $(\mathrm{n}=2)$ & $306 \pm 42$ & $12.0 \pm 2.8$ & $25.8 \pm 2.6$ \\
\hline \multirow[t]{2}{*}{ 2008-2009 } & Delta-Makgadikgadi $(\mathrm{n}=5)$ & $274 \pm 33$ & $10.4 \pm 2.5$ & $27.9 \pm 9.4$ \\
\hline & Makgadikgadi-Delta $(\mathrm{n}=5)^{\star}$ & $254 \pm 17$ & $8.7 \pm 2.1$ & $30.5 \pm 8.2$ \\
\hline
\end{tabular}

*The zebra first returned to the Okavango Delta in May 2009; only one GPS collar continued working after this period. 


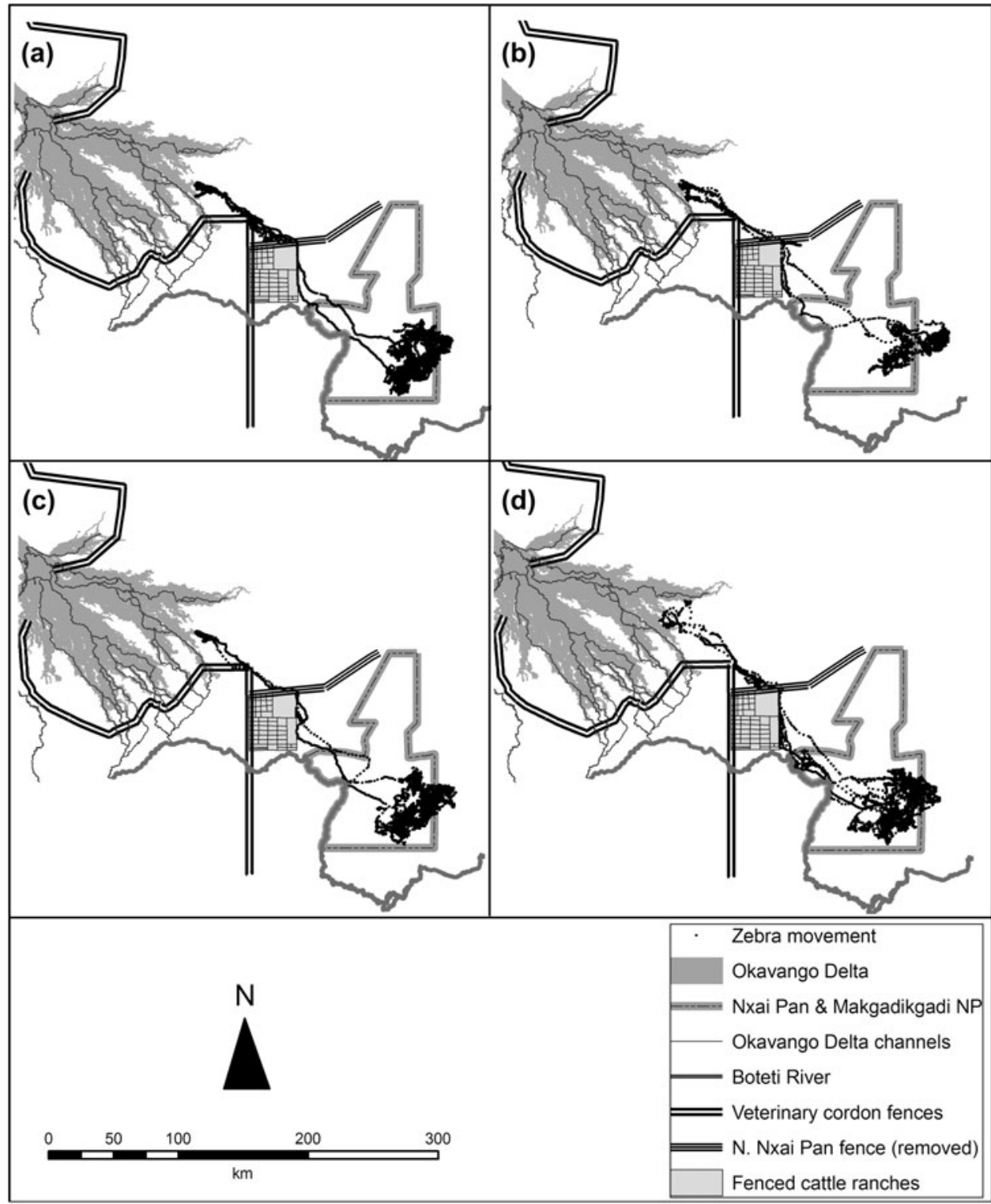

Fig. 3 Movements of four zebra mares between the Okavango Delta and the Makgadikgadi Pans grasslands: (a) outward journey in November 2007 and return journey in May 2008; (b) outward journey in November 2007 and return journey in May 2008; (c) outward journey in November 2008 and return journey in April 2009; (d) four journeys between November 2008 and October 2009.

century (Albertson, 1998); these are the only type of records available for this period. However, during 1968-2004 this route was bisected by the northern Nxai Pan veterinary cordon fence and throughout this 36-year period zebras could not follow the route we recorded. A study of zebra and wildebeest in the Makgadikgadi system between 2000 and 2004 did not record any movements towards the Okavango Delta (C.J. Brooks, pers. comm.), nor is such a movement described by Kgathi \& Kalikawe (1993). While it is not formally documented what happened to the migration during this period, anecdotal accounts report that zebra and other herbivores came into contact with the fence, with carcasses being found near the point at which our collared zebra crossed the old fence line (Albertson,
1998). Although it cannot be ruled out that animals walked round the fence, a return trip of $200 \mathrm{~km}$ around the eastern end of the fence seems unlikely. Such a journey would have taken c. 10 additional days at the rates of travel we recorded and would have passed through arid scrub with no permanent water, although it is probable that rainwater puddles would have been available on the outward trip from the delta because the zebra we monitored left the delta after the first rains. However, on the return trip, water would have been extremely limited or non-existent because the collared zebra did not leave the Makgadikgadi until the vast majority of the waterholes had dried up. It seems more probable that the majority, if not all, zebra and other similar-sized herbivores failed to complete this 
migratory movement during the period the fence was in existence.

A possible explanation for the highly directed movement we recorded is that the historical migration has been re-established. An alternative explanation could be that the zebra made exploratory movements into the newly accessible area and established a new migration. Either explanation is of significant conservation interest as it illustrates the ability of medium-sized herbivores to re-establish a historical migration or undertake sufficient long-distance explanatory movements to establish a new migration within 4 years of the removal of a physical barrier. It is important to identify highly utilized movement corridors and stopover points on ungulate migratory routes (Sawyer et al., 2009). The GPS collar data suggested that during the study the route and stopover points used by the zebras did not vary substantially between individuals or years.

While the factors controlling migration in ungulates are not well understood, studies on insects and birds suggest that genetic, social and environmental factors are important, with species-specific differences in the importance of each factor (Schüz, 1949; Berthold et al., 1990; Olsen, 2001a,b; Chernetsov et al., 2004). Our results suggest that there may also be some genetic component of migration by ungulates. With a life expectancy of 15 years (Smuts, 1975), none of the zebra we recorded undertaking this migratory route could have learnt it from parental harems while juveniles. However, the stimulus to migrate must have been maintained, such that they resumed their migration once the fence was removed. The route taken could be because of innate directional cues, or perhaps by undertaking exploratory movements, following tracks of species such as elephants that also move great distances. While migratory birds such as whooping cranes Grus americana, which rely on strong social stimuli, only restart migratory behaviour after being re-taught the migratory route (Olsen, 2001a,b), terrestrial mammals may be better able to re-establish migratory behaviour because of the shorter distances travelled and the greater importance of environmental cues.

Wildlife corridors are widely advocated as the best way to link fragmented ecosystems or isolated habitats to re-establish ecosystem connectivity (Harris \& Scheck, 1991). However, the success of these schemes relies heavily on animals moving either permanently or seasonally between the connected areas. Although long-lived mammals such as elephants utilize novel areas, uptake is slow and animals are initially cautious (Druce et al., 2008). Hitherto, there is little published data on how ungulates respond to the availability of areas that have been inaccessible for at least one generation. Our results suggest that they may be able to re-establish old migratory routes or establish new long-distance movements relatively quickly once physical barriers have been removed and that the success of future system linkages could be increased by utilizing extinct migratory routes.

\section{Acknowledgements}

We thank the Botswana Ministry for the Environment, Wildlife and Tourism and the Botswana Department of Wildlife and National Parks for research permits and logistical support, the Leverhulme Trust, Wilderness Trust (to HLABB) and Dulverton Trust (to $\mathrm{SH}$ ) for funding, D. Hawk and R. Jackson for undertaking the veterinary procedures, and C.J. Brooks, G. Hopcraft and an anonymous reviewer for helpful comments .

\section{References}

Albertson, A. (1998) Northern Botswana Veterinary Fences: Critical Ecological Impacts. Botswana Okavango People's Wildlife Trust, Maun, Botswana.

Andersson, L., Gumbricht, T., Hughes, D., Kniveton, D., Ringrose, S., Savenije, H. et al. (2003) Water flow dynamics in the Okavango River Basin and Delta-a prerequisite for the ecosystems of the Delta. Physics and Chemistry of the Earth, 28, $1165-1172$.

Baillieul, T.A. (1979) Makgadikgadi Pans complex of central Botswana: summary. Geological Society of America Bulletin, 90, 133-136.

Berger, J. (2004) The last mile: how to sustain long-distance migration in mammals. Conservation Biology, 18, 320-331.

Berthold, P., Wiltschio, W., Miltenberger, H. \& Querner, U. (1990) Genetic transmission of migratory behavior into a non-migratory bird population. Experientia, 46, 107-108.

Bolger, D.T., Newmark, W.D., Morrison, T.A. \& Doak, D.F. (2008) The need for integrative approaches to understand and conserve migratory ungulates. Ecology Letters, 11, 63-77.

Bonyongo, M.C. (2004) The ecology of large herbivores in the Okavango Delta, Botswana. PhD thesis, University of Bristol, Bristol, UK.

B Rоокs, C.J. (2005) The foraging behaviour of Burchell's zebra (Equus burchelli antiquorum). PhD thesis, University of Bristol, Bristol, UK.

Brooks, C.J. \& Harris, S. (2008) Directed movement and orientation across a large natural landscape by zebras, Equus burchelli antiquorum. Animal Behaviour, 76, 277-285.

Chernetsov, N., Berthold, P. \& Querner, U. (2004) Migratory orientation of first-year white storks (Ciconia ciconia): inherited information and social interactions. Journal of Experimental Biology, 207, 937-943.

Cronberg, G., Gieske, A., Martins, E., Prince Nengu, J. \& Stenström, I.-M. (1996) Major ion chemistry, plankton and bacterial assemblages of the Jao/Boro River, Okavango Delta, Botswana: the swamps and flood plains. Archiv für Hydrobiologie, 107, supplement, 335-407.

Diamond, J.M. (1975) The island dilemma: lessons of modern biogeographic studies for the design of natural reserves. Biological Conservation, 7, 129-146.

Dingle, H. (1996) Migration: The Biology of Life on the Move. Oxford University Press, Oxford, UK.

Druce, H.C., Pretorius, K. \& Slotow, R. (2008) The response of an elephant population to conservation area expansion: Phinda Private Game Reserve, South Africa. Biological Conservation, 141, 3127-3138.

Ebedes, H. (1971) The capture of plains zebra, Equus burchelli antiquorum, with M99 (Etorphine Rickett) and tranquilizers in the Etosha National Park. Madoqua, 1, 67-76. 
FRYXELL, J.M. (1987) Food limitation and demography of a migratory antelope, the white-eared kob. Oecologia, 72, 83-91.

Fryxell, J.M., Greever, J. \& Sinclair, A.R.E. (1988) Why are migratory ungulates so abundant? American Naturalist, 131, 781798.

FryXell, J.M. \& Sinclair, A.R.E. (1988) Causes and consequences of migration by large herbivores. Trends in Ecology \& Evolution, 3, 237-241.

Harris, G., Thirgood, S., Hopcraft, J.G.C., Cromsigt, J.P.G.M. \& BERGER, J. (2009) Global decline in aggregated migrations of large terrestrial mammals. Endangered Species Research, 7, 55-76.

HARRIS, L.D. \& SCHECK, J. (1991) From implications to applications: the dispersal corridor principle applied to the conservation of biological diversity. In Nature Conservation 2: The Role of Corridors (eds D.A. Saunders \& R.J. Hobbs), pp. 189-200. Surrey Beatty \& Sons, Chipping Norton, Australia.

Keene-Young, R. (1999) A thin line: Botswana's cattle fences. Africa Environment and Wildlife, 7, 71-79.

Kgathi, D.K. \& Kalikawe, M.C. (1993) Seasonal distribution of zebra and wildebeest in Makgadikgadi Pans Game Reserve, Botswana. African Journal of Ecology, 31, 210-219.

Klingel, H. (1969) The social organization and population ecology of the plains zebra (Equus quagga). Zoologica Africana, 4, 249-263.

McCarthy, T.S. \& Ellery, W.N. (1998) The Okavango Delta. Transactions of the Royal Society of South Africa, 53, 157-182.

McNaughton, S.J. (1990) Mineral nutrition and seasonal movements of African migratory ungulates. Nature, 345, 613-615.

Mduma, S.A.R., Sinclair, A.R.E. \& Hilborn, R. (1999) Food regulates the Serengeti wildebeest: a 40-year record. Journal of Animal Ecology, 68, 1101-1122.

Olsen, G.H. (2001a) Of cranes and men: reintroduction of cranes to a migratory pathway-part I. Journal of Avian Medicine and Surgery, 15, 133-137.

Olsen, G.H. (2001b) Of cranes and men: reintroduction of cranes to a migratory pathway-part II. Journal of Avian Medicine and Surgery, 15, 316-322.

Perkins, J.S. (1996) Botswana: fencing out the equity issue. Cattleposts and cattle ranching in the Kalahari Desert. Journal of Arid Environments, 33, 503-517.

Roche, C. (2008) 'The fertile brain and inventive power of man': anthropogenic factors in the cessation of springbok treks and the disruption of the Karoo ecosystem, 1865-1908. Africa, 78, 157-188.
Sawyer, H., Kauffman, M.J., Nielson, R.M. \& Horne, J.S (2009) Identifying and prioritizing ungulate migration routes for landscape-level conservation. Ecological Applications, 19, 2016-2025.

SCHÜZ, E. (1949) Die Spätauflassung ostpreussischer Jungstörche in Westdeutschland durch die Vogelwarte Rossitten 1933. Vogelwarte, $15,63-78$.

SinClair, A.R.E. (1979) Dynamics of the Serengeti ecosystem: process and pattern. In Serengeti (eds A.R.E. Sinclair \& M. Norton-Griffiths), pp. 1-30. University of Chicago Press, Chicago, USA.

Sinclair, A.R.E. \& Arcese, P. (1995) Serengeti II: Dynamics, Management, and Conservation of an Ecosystem. University of Chicago Press, Chicago, USA.

Skinner, J.D. \& Smithers, R.H.N. (1990) The Mammals of the Southern African Subregion. University of Pretoria, Pretoria, South Africa.

Smuts, G.L. (1975) Pre- and postnatal growth phenomena of Burchell's zebra (Equus burchelli antiquorum). Koedoe, 18, 69-102.

VAndew Alle, M.E. (2000) Movement of zebra and wildebeest in relation to environmental factors in northern Botswana. $\mathrm{PhD}$ thesis, University of the Witwatersrand, Johannesburg, South Africa.

Williamson, D., Williamson, J. \& NGwamotsoko, K.T. (1988) Wildebeest migration in the Kalahari. African Journal of Ecology, $26,269-280$.

\section{Biographical sketches}

Hattie BARTLAm-Brooks has particular interests in the influence of resources on herbivore distribution and movement patterns and the use of such data in land-use management and applied conservation. CASPER BONYONGO is currently conducting and leading a number of research projects on the ecology of large herbivores in northern Botswana. His main research area is large herbivore community ecology, in particular resource utilization by coexisting herbivores. STEPHEN HARRIS has wide interests in mammalian ecology and conservation biology, with particular interests in the management of invasive species, the social systems and spatial requirements of large mammals, the adaptations of mammals to urban ecosystems and the restoration of ecosystem functions through the use of taxon substitutes. 